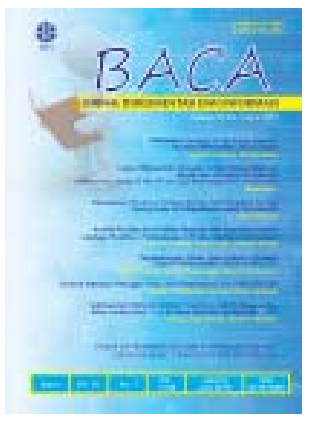

\title{
KORELASI ANTARFAKTOR KEPUASAN KERJA PUSTAKAWAN: STUDI KASUS PUSTAKAWAN LEMBAGA ILMU PENGETAHUAN INDONESIA
}

\author{
Dwiatri Kusumaningrum $^{1 *}$, Seno Yudhanto ${ }^{2}$, Ambar Yoganingrum ${ }^{3}$ \\ 1,2,3 Pusat Dokumentasi dan Informasi Ilmiah LIPI \\ 1*Korespondensi: aroem_ndalu@yahoo.com
}

Diajukan: 6-2-2016; Direview: 23-2-2016; Diterima: 5-3-2016; Direvisi: 5-6-2016

\begin{abstract}
Librarian job satisfaction is influenced by a number of factors, among others, the working environment, motivation, and compensation. Knowing the relationship between these factors will be helpful for the improvement of job satisfaction, which in turn will improve the professionalism of librarians. This study aims to measure the correlation between these factors. Respondents are librarians within Indonesian Institute of Science, with the post of librarian executing, implementing advanced, supervisors, first, the young and middle. Collecting data using questionnaires, while the correlation measurement using the method of Kendal and Spearman. The study results show that there is no significant relationship between work environment factors and compensation as well as among the factors of motivation and compensation.
\end{abstract}

\begin{abstract}
ABSTRAK
Kepuasan kerja pustakawan dipengaruhi oleh sejumlah faktor, yaitu lingkungan kerja, motivasi, dan kompensasi. Diketahuinya hubungan antarfaktor akan bermanfaat untuk perbaikan kepuasan kerja, kemudian akan meningkatkan profesionalitas pustakawan. Kajian ini bertujuan untuk mengukur korelasi antarfaktor tersebut. Responden adalah pustakawan di Lembaga Ilmu pengetahuan Indonesia, dengan jabatan pustakawan pelaksana, pelaksana lanjutan, penyelia, pertama, muda dan madya. Pengumpulan data menggunakan kuesioner. Pengukuran korelasi menggunakan metoda Kendal dan Spearman. Hasil kajian memperlihatkan bahwa terdapat hubungan yang tidak signifikan antara faktor lingkungan kerja dan kompensasi serta antara faktor motivasi dan kompensasi.
\end{abstract}

Keywords: Librarian; Job satisfaction; Work environment; Motivation; Compensation

\section{PENDAHULUAN}

Dewasa ini perpustakaan dituntut untuk bersifat dinamis, yaitu dapat menyesuaikan setiap perubahan yang terjadi di masyarakat. Perubahan perpustakaan dapat dilihat dari berbagai aspek, seperti koleksi, fasilitas, maupun layanan. Pergeseran media informasi yang semula berbentuk fisik/ tercetak menjadi online/digital. Kemudahan akses terhadap informasi melalui jaringan internet menyebabkan masyarakat lebih memilih search engine untuk mendapatkan informasi daripada datang 
ke perpustakaan dan bertanya pada pustakawan. Semakin berkembangnya ilmu pengetahuan dan teknologi membuat peran perpustakaan dan pustakawan menjadi penting. Pustakawan dituntut untuk memberikan kinerja nyata sebagai rantai penghubung informasi ke pemustaka (Kohar, 2011).

Profesi pustakawan sudah diakui sebagai jabatan khusus yang tercantum dalam undang-undang dan peraturan. Pada Undang-Undang No 43 Tahun 2007, pustakawan digambarkan sebagai seseorang yang memiliki kompetensi yang diperoleh melalui pendidikan dan/atau pelatihan kepustakawanan serta mempunyai tugas dan tanggung jawab untuk melaksanakan pengelolaan dan pelayanan perpustakaan. Peraturan Menteri Pendayagunaan Aparatur Negara dan Reformasi Birokrasi Republik Indonesia Nomor 9 Tahun 2014 menyebutkan pustakawan adalah mereka yang berstatus PNS yang diberi tugas dan tanggung jawab untuk melaksanakan kegiatan kepustakawanan. Tugas dan tanggung jawab diperlukan untuk menilai sejauh mana kualitas kinerja yang dimiliki profesi pustakawan.

Pada era globalisasi, tuntutan dan tantangan profesi pustakawan semakin besar untuk memenuhi kebutuhan informasi pemustaka. Adanya peralihan sistem manual ke sistem digital menandakan bahwa peningkatan kualitas kinerja pustakawan mutlak diperlukan. Suharti (2009) menyatakan bahwa kualitas kinerja pustakawan bergantung pada tingkat kepuasan kerja pustakawan. Semakin tinggi kepuasan kerja pustakawan maka semakin baik kualitas kinerjanya. Sebaliknya, semakin rendah kepuasan kerja pustakawan semakin rendah pula kualitas kinerja yang dihasilkan. Hal ini tentunya berdampak pada kualitas organisasi, perpustakaan/pusat dokumentasi dan informasi dalam memberikan layanan informasi kepada para pemustaka.

Lembaga Ilmu Pengetahuan Indonesia (LIPI) sebagai lembaga riset terbesar di Indonesia memiliki sejumlah perpustakaan di setiap satuan/unit kerja. Pada beberapa perpustakaan di satuan kerja terdapat beberapa pustakawan yang bertugas untuk mengelola dan mengolah sumber-sumber informasi ilmiah guna kelangsungan penelitian yang dilakukan oleh para peneliti, khususnya peneliti LIPI. Berdasarkan data Biro Organisasi dan Sumber Daya Manusia LIPI (BOSDM LIPI), sampai dengan April 2016 tercatat sebanyak 55 orang sivitas LIPI yang memiliki jabatan fungsional pustakawan. Jumlah tersebut tersebar di masing-masing satuan kerja yang terdapat di LIPI. Pustakawan LIPI tersebut memiliki status sebagai Pegawai Negeri Sipil (PNS).

Permasalahan penelitian ini adalah: (1) faktor-faktor apa yang mempengaruhi kepuasan kerja pustakawan LIPI?; dan (2) bagaimana korelasi antarfaktor tersebut. Tujuan penelitian ini untuk: (1) mengidentifikasi faktor-faktor yang mempengaruhi kepuasan kerja pustakawan di lingkungan LIPI; dan (2) mengetahui korelasi antarfaktor tersebut. Keluaran dari penelitian ini adalah data mengenai faktor-faktor yang mempengaruhi kepuasan kerja pustakawan dan ada tidaknya korelasi antarfaktor. Pengetahuan mengenai faktor-faktor dan korelasi antarfaktor dapat digunakan untuk memperbaiki kinerja pustakawan. Hasil penelitian dapat diterapkan oleh seluruh pustakawan yang bekerja di semua jenis perpustakaan, termasuk perpustakaan khusus instansi pemerintah.

\section{TINJAUAN PUSTAKA}

Pembahasan mengenai faktor-faktor yang mempengaruhi kepuasan kerja pustakawan telah dilakukan beberapa peneliti sebelumnya. Faktor-faktor kepuasan kerja pustakawan, meliputi faktor lingkungan kerja (Ikonne dan Onuoha, 2015; Jumarlita, 2015; Suharti, 2009; Santoso 2015; Khoiri 
2013; Maithili dan Navaneethakrishnan, 2014; Ciptaningrum, 2009); faktor motivasi (Amune, 2013; Tella, 2007; Santoso 2015; Khoiri 2013; Sumbaningsih dan Nelisa, 2013; Dinahaji, 2012); dan faktor kompensasi (Odunlade, 2012; Owolabi dan Salaam, 2010; Ciptaningrum, 2009; Dinahaji 2012).

\section{1) Faktor Lingkungan Kerja}

Lingkungan kerja merupakan salah satu faktor yang perlu diperhatikan dalam organisasi perpustakaan. Menurut Sutrisno dalam Khoiri (2013) lingkungan kerja adalah keseluruhan sarana dan prasarana kerja yang ada di sekitar karyawan yang sedang melakukan pekerjaan yang dapat mempengaruhi pelaksanaan pekerjaan, meliputi tempat bekerja, fasilitas, kebersihan, pencahayaan, ketenangan, termasuk juga hubungan kerja antara orang-orang yang ada di tempat tersebut. Pengelompokan kondisi dari lingkungan kerja oleh Newstorm dalam Kinanti (2012) dibagi menjadi dua, yaitu kondisi fisik dan non-fisik. Kondisi fisik yang dimaksud meliputi pencahayaan, suhu udara, tingkat kebisingan, radiasi udara, ciri-ciri estetis, seperti warna dinding, lantai, musik, tumbuhtumbuhan, atau hal-hal yang menghiasi tempat bekerja. Sementara lingkungan kerja non-fisik menekankan pada adanya hubungan antara atasan-bawahan dan antar rekan kerja.

Beberapa penelitian menyebutkan bahwa faktor lingkungan kerja memiliki hubungan dengan kepuasan kerja pustakawan (Ikonne dan Onuoha, 2015; Jumarlita, 2015; Suharti, 2009; Santoso 2015; Khoiri 2013; Maithili dan Navaneethakrishnan, 2014; Ciptaningrum, 2009). Penelitian tersebut menyebutkan bahwa faktor lingkungan kerja merupakan faktor yang signifikan mempengaruhi kepuasan kerja pustakawan di perpustakaan perguruan tinggi, Maithili dan Navaneethakrishnan (2014) yang meneliti untuk pustakawan sekolah. Selain dengan kepuasan kerja, faktor lingkungan kerja juga berpengaruh pada motivasi kerja (Khoiri, 2013; Santoso, 2015). Aspek-aspek dari faktor lingkungan kerja yang berhubungan dengan kepuasan kerja pustakawan meliputi hubungan dengan atasan/pimpinan (Ikonne dan Onuoha, 2015; Jumarlita, 2015; Santoso, 2015; Maithili dan Navaneethakrishnan, 2014; Leysen dan Boydston , 2009; Ciptaningrum, 2009), hubungan dengan rekan kerja (Suharti, 2009; Santoso, 2015; Maithili dan Navaneethakrishnan, 2014; Leysen dan Boydston , 2009; Ciptaningrum, 2009), ruangan yang bersih dan nyaman (Suharti, 2009; Santoso, 2015; Khoiri, 2013), dan pengaturan suhu ruangan (Suharti, 2009; Santoso, 2015; Khoiri, 2013; Ciptaningrum, 2009).

\section{2) Faktor Motivasi}

Menurut Robbins dalam Juniantara (2015), motivasi adalah cara untuk mengerahkan upaya terbaik yang dimiliki oleh seseorang untuk mencapai sasaran yang ditentukan oleh organisasi. Untuk mengerahkan upaya tersebut, biasanya organisasi akan/sudah memberikan imbalan atas kinerja yang dicapai. Motivasi lahir dari keinginan dari dalam diri seseorang untuk melakukan atau tidak melakukan sesuatu yang diyakininya.

Pada prinsipnya, motivasi dapat dibagi menjadi dua, yaitu motivasi positif dan motivasi negatif (Hasibuan dalam Sumbangsih dan Nelisa, 2013). Motivasi positif dapat diartikan bahwa atasan/pimpinan memotivasi (merangsang) bawahan dengan memberikan hadiah/reward kepada mereka yang berprestasi standar pekerjaan yang telah ditetapkan organisasi. Sementara motivasi negatif dapat diartikan bahwa atasan/pimpinan memotivasi bawahan dengan standar mereka akan 
mendapat hukuman/punishment.

Faktor motivasi menjadi salah satu faktor yang memiliki hubungan dengan kepuasan kerja pustakawan. Faktor motivasi secara signifikan memiliki hubungan yang kuat dengan kepuasan kerja di perpustakaan perguruan tinggi (Amune, 2013; Tella, 2007; Sumbangsih dan Nelisa, 2013; Dinahaji, 2012). Dalam faktor motivasi, aspek yang dapat ditinjau sebagai indikator adalah kepercayaan diri (Santoso, 2015; Leysen dan Boydston, 2009; Winarandu dan Marlini, 2013), berusaha keras (Santoso, 2015; Khoiri, 2013), bekerja untuk memenuhi kebutuhan (Santoso, 2015; Sumbangsih dan Nelisa, 2013), dukungan dari pihak luar (Winarandu, 2013), dan adanya kesempatan pengembangan diri/karir (Amune, 2013; Khoiri, 2013; Sook Lim, 2008; Haque et al, 2012; Tella, 2007; Diniaty dan Fairus, 2014; Maithili dan Navaneethakrishnan, 2014).

\section{3) Faktor Kompensasi}

Kompensasi menurut Simamora dalam Kartini (2011), yaitu istilah luas yang berkaitan dengan imbalan-imbalan (finance reward) yang diterima oleh karyawan melalui kepegawaian mereka dalam sebuah organisasi. Kompensasi tidak hanya berupa uang namun kompensasi dapat berupa kenaikan pangkat atau penghargaan. Menurut McNamara dalam Odunlade (2012), kompensasi mencakup hal yang bersifat materi maupun non-materi. Kompensasi terdiri dari gaji, tunjangan, dan penghargaan (Odunlade, 2012; Dinahaji, 2012; Kavitha dan Jayaraman, 2015; Murray, 1999; Haque et al, 2012; Ciptaningrum, 2009; Maithili dan Navaneethakrishnan, 2014).

\section{METODE}

Penelitian ini menggunakan metode Spearman dan Kendall untuk mengukur korelasi antarfaktor. Korelasi adalah keeratan hubungan yang dimiliki antarvariabel atau faktor dalam penelitian. Syarat penghitungan korelasi dengan menggunakan metode korelasi Spearman dan Kendall adalah semua variabel berbentuk ordinal, artinya isi variabel berjenjang, seperti sangat baik, baik, tidak baik dan sebagainya (Santoso, 2001). Penelitian ini mengukur korelasi antarfaktor yang mempengaruhi kepuasan kerja pustakawan, yaitu faktor lingkungan kerja, faktor motivasi, dan faktor kompensasi. Faktor lingkungan kerja, terdiri dari hubungan dengan atasan/pimpinan, hubungan dengan rekan kerja, ruangan yang bersih, pengaturan suhu, dan kelembaban. Faktor motivasi terdiri dari percaya diri, bekerja keras, memenuhi kebutuhan hidup, dukungan pihak luar, dan pengembangan karir. Sementara pada faktor kompensasi indikator yang diteliti meliputi gaji, tunjangan, dan penghargaan (non-materi).

Pengumpulan data menggunakan kuesioner. Objek penelitian ini adalah hubungan antarfaktor yang mempengaruhi kepuasan kerja pustakawan. Subjek penelitian ini adalah pustakawan yang aktif di LIPI. Populasi penelitian adalah pustakawan yang bekerja dan berstatus aktif di LIPI. Responden penelitian merupakan seluruh populasi yang berjumlah 55 orang. Dalam penelitian ini, bentuk pertanyaan yang digunakan pada kuesioner bersifat kuesioner tertutup. Pertanyaan kuesioner dibuat dengan menggunakan aplikasi google form. Penyebaran kuesioner dilakukan dua cara, yaitu melalui email dan sebagian dicetak untuk diisi secara manual. Kuesioner menggunakan Skala Likert, yang terdiri dari lima butir jawaban dengan bobot dari tiap pernyataan tersebut sebagai berikut:

- 5 untuk jawaban Sangat Setuju; 
- 4 untuk jawaban Setuju;

- 3 untuk jawaban Netral;

- 2 untuk jawaban Tidak Setuju;

- 1 untuk jawaban Sangat Tidak Setuju.

Hipotesis penelitian ini sebagai berikut:

a. $\mathrm{H} 0=$ Terdapat pengaruh yang signifikan antara lingkungan kerja terhadap motivasi kerja pegawai perpustakaan.

b. $\quad$ H1 = Tidak terdapat pengaruh yang signifikan antara lingkungan kerja terhadap motivasi kerja pegawai perpustakaan.

c. $\quad$ H0 = Terdapat pengaruh yang signifikan antara lingkungan kerja terhadap kompensasi.

d. H1 = Tidak terdapat pengaruh yang signifikan antara lingkungan kerja terhadap kompensasi.

e. H0 : Terdapat pengaruh yang signifikan antara kompensasi terhadap motivasi kerja pegawai perpustakaan.

f. H1 : Tidak terdapat pengaruh yang signifikan antara kompensasi terhadap motivasi kerja pegawai perpustakaan.

Pada penelitian ini, pengolahan data menggunakan alat bantu, yaitu aplikasi Microsoft Excel dan SPSS.

\section{HASIL DAN PEMBAHASAN}

Berdasarkan data analisis diketahui data responden sebagai berikut (Tabel 1).

Tabel 1. Menyajikan Data Responden

\begin{tabular}{|c|l|l|l|}
\hline No. & Data responden & Jumlah & Prosentase \\
\hline & Jenjang pustakawan & & \\
\hline 1 & Pustakawan pelaksana & 1 orang & $3 \%$ \\
2 & Pustakawan pelaksana lanjutan & 1 orang & $3 \%$ \\
3 & Pustakawan penyelia & 9 orang & $27,3 \%$ \\
4 & Pustakawan pertama & 2 orang & $6,1 \%$ \\
5 & Pustakawan muda & 11 orang & $33,3 \%$ \\
6 & Pustakawan madya & 9 orang & $27,3 \%$ \\
\hline & Jenis kelamin & & \\
\hline 1 & Laki-laki & 10 orang & $30,3 \%$ \\
2 & Perempuan & 23 orang & $69,7 \%$ \\
\hline & Usia responden & & \\
\hline 1 & $25-35$ tahun & 4 orang & $12,1 \%$ \\
2 & $36-45$ tahun & 5 orang & $15,2 \%$ \\
3 & $46-55$ tahun & 17 orang & $51,5 \%$ \\
4 & $56-65$ tahun & & $21,2 \%$ \\
\hline & & & \\
\hline
\end{tabular}


BACA: Jurnal Dokumentasi dan Informasi, 37 (1) Juni 2016, Halaman : 1-10

\begin{tabular}{|l|l|l|l|}
\hline & Pendidikan terakhir & & \\
\hline 1 & SMA & 7 orang & $21,2 \%$ \\
2 & D3 & 3 orang & $9,1 \%$ \\
3 & S1 & 11 orang & $33,3 \%$ \\
4 & S2 & 12 orang & $36,4 \%$ \\
\hline & Masa kerja & & \\
\hline 1 & $1-5$ tahun & - & - \\
2 & $6-10$ tahun & 5 orang & $15,2 \%$ \\
3 & $11-15$ tahun & 4 orang & $12,1 \%$ \\
4 & $16-20$ tahun & 1 orang & $3 \%$ \\
5 & $>20$ tahun & 23 orang & $69,7 \%$ \\
\hline
\end{tabular}

Tabel 1 menunjukkan data responden dari hasil kuesioner yang disebar keseluruh populasi yang berjumlah 55 orang. Dari jumlah tersebut, kuesioner yang kembali sebanyak 33 buah. Data dari hasil kuisioner selanjutnya dianalisis menggunakan metode Spearman dan Kendall.

Tabel 2 menyajikan hasil analisis faktor korelasi antarfaktor kepuasan kerja menggunakan metode Spearman dan Kendall.

Tabel 2. Hasil Analisis Korelasi AntarFaktor Kepuasan Kerja

\begin{tabular}{|c|c|c|c|c|c|}
\hline \multicolumn{6}{|c|}{ Correlations } \\
\hline & & & $\begin{array}{l}\text { Lingkungan } \\
\text { Kerja }\end{array}$ & Motivasi & Kompensasi \\
\hline \multirow[t]{9}{*}{ Kendall's tau_b } & \multirow[t]{3}{*}{ Lingkungan Kerja } & Correlation Coefficient & 1,000 &, 368 & ,105 \\
\hline & & Sig. (2-tailed) & & 007 & ,459 \\
\hline & & $\mathrm{N}$ & 33 & 33 & 33 \\
\hline & \multirow[t]{3}{*}{ Motivasi } & Correlation Coefficient &, $368^{\text {t* }}$ & 1,000 &, $308^{*}$ \\
\hline & & Sig. (2-tailed) &, 007 & . & 029 \\
\hline & & $N$ & 33 & 33 & 33 \\
\hline & \multirow[t]{3}{*}{ Kompensasi } & Correlation Coefficient & ,105 &, $308^{*}$ & 1,000 \\
\hline & & Sig. (2-tailed) & ,459 &, 029 & . \\
\hline & & $\mathrm{N}$ & 33 & 33 & 33 \\
\hline \multirow[t]{9}{*}{ Spearman's rho } & \multirow[t]{3}{*}{ Lingkungan Kerja } & Correlation Coefficient & 1,000 & $485^{\text {t* }}$ & ,119 \\
\hline & & Sig. (2-tailed) & &, 004 &, 510 \\
\hline & & $N$ & 33 & 33 & 33 \\
\hline & \multirow[t]{3}{*}{ Motivasi } & Correlation Coefficient & $485^{\text {*t }}$ & 1,000 & $374^{*}$ \\
\hline & & Sig. (2-tailed) &, 004 & & 032 \\
\hline & & $N$ & 33 & 33 & 33 \\
\hline & \multirow[t]{3}{*}{ Kompensasi } & Correlation Coefficient & ,119 &, $374^{\star}$ & 1,000 \\
\hline & & Sig. (2-tailed) &, 510 & 032 & . \\
\hline & & $\mathrm{N}$ & 33 & 33 & 33 \\
\hline
\end{tabular}

${ }^{\star \star}$. Correlation is significant at the 0.01 level (2-tailed).

${ }^{*}$. Correlation is significant at the 0.05 level (2-tailed).

Tabel 2 menunjukkan bahwa korelasi antara lingkungan kerja dengan motivasi adalah positif (0.368) serta mempunyai hubungan yang signifikan (0.007). Hal ini mengartikan semakin bagus/kondusif lingkungan kerja maka pustakawan semakin termotivasi untuk bekerja, demikian sebaliknya semakin kurang bagus/kurang kondusif lingkungan kerja mengakibatkan pustakawan kurang termotivasi untuk bekerja. 
Lingkungan kerja sangat mempengaruhi motivasi pekerja (Khoiri, 2013; Santoso, 2015; Arnseta dan Rachman, 2013). Khoiri (2013) dalam penelitiannya faktor lingkungan kerja yang diteliti meliputi pewarnaan, kebersihan udara, penerangan, kebisingan, keamanan kerja, hubungan kerja dengan atasan, dan hubungan kerja dengan rekan kerja. Keadaan lingkungan kerja yang kondusif akan memotivasi pustakawan dalam melaksanakan tugas dan fungsinya untuk mencapai tujuan pustakawan serta memberikan semangat kerja secara langsung maupun tidak langsung terhadap pustakawan (Santoso, 2015).

Korelasi faktor lingkungan kerja dengan kompensasi adalah positif (0.105), tetapi hubungan antarkedua faktor tersebut tidak signifikan (0.459). Hasil yang diperoleh yaitu semakin baik/kondusif lingkungan kerja semakin meningkatkan kompensasi pustakawan, semakin kurang kondusif lingkungan kerja maka kompensasi seorang pustakawan juga turun. Santoso (2015) menjelaskan bahwa lingkungan kerja yang kondusif akan memotivasi pustakawan dalam melaksanakan tugas dan fungsinya untuk mencapai tujuan pustakawan serta memberikan semangat kerja pustakawan secara langsung maupun tidak langsung. Semangat kerja yang timbul meningkatkan efisiensi dan produktivitas kerja staf perpustakaan. Meningkatnya produktivitas kerja akan meningkat pula kinerja pustakawan. Hal tersebut berpengaruh pada meningkatnya kompensasi yang diterima oleh karyawan. Kompensasi yang diterima berupa: (1) gaji; (2) tunjangan; (3) pengharagaan. Dalam pemberian kompensasi harus memperhatikan: (1) kondisi individu, sehingga tidak memberikan kompensasi dengan pertimbangan subjektif dan diskriminatif; (2) berdasarkan kinerja dan ketrampilam karyawan sehingga dapat memuaskan karyawan serta karyawan semakin termotivasi meningkatkan kinerjanya (Mulyani, 2002).

Diperoleh hasil bahwa motivasi berpengaruh positif namun tidak signifikan terhadap faktor kompensasi (0.29). Hasil tersebut menunjukkan semakin termotivasinya pustakawan dalam bekerja, kompensasi yang diterima seorang pustakawan juga semakin baik/banyak (Fauzie, 2009; Santoso, 2015; Puspita, 2015). Faktor kompensasi merupakan salah satu faktor pendorong motivasi (Puspita, 2015) sehingga faktor kompensasi dan motivasi mempengaruhi kinerja pegawai (Fauzie, 2009). Sumbaningsih dan Nelisa (2013) menjelaskan bahwa pemberian insentif tidak mempengaruhi motivasi kerja pustakawan karena dalam penelitiannya pemberian insentif diberikan secara merata kepada semua pegawai tanpa melihat beberapa faktor, seperti prestasi kerja, beban pekerjaan, jenjang pendidikan.

\section{KESIMPULAN}

Pustakawan LIPI berpendapat bahwa korelasi antara faktor lingkungan kerja, kompensasi, serta antara faktor motivasi dan kompensasi tidak signifikan. Diasumsikan bahwa kompensasi yang diberikan kepada pustakawan belum mempertimbangkan aspek prestasi kerja, beban pekerjaan, dan jenjang pendidikan. Penelitian ini dapat digunakan sebagai bahan masukkan untuk perbaikan sistem kompensasi guna meningkatkan kepuasan kerja pustakawan. Penelitian ini sebaiknya dilakukan secara periodik sebagai bahan untuk melakukan penataan dan perbaikan lingkungan kerja.

\section{DAFTAR PUSTAKA}

Amune, Juliana Bisede. 2013. Job Motivation as A Predictor of Job Satisfaction Among Professional and Non-Professional Library Staff in Ambrose Alli University, Ekpoma. International Journal of 
Innovative Research \& Development. Vol.2, Issue 5, May: 1477-1497.

Arnesta, Tya dan Rachman, Yeni Budi. 2013. "Motivasi Kerja Tenaga Perpustakaan di Perpustakaan Badan Penelitian dan Pengembangan Kementerian Dalam Negeri”. (http://lontar.ui.ac.id/ naskahringkas/2016-03/S52718-Tya\%20Arnesta, diakses 6 Juni 2016).

Ciptaningrum, Asri. 2009. "Kepuasan Kerja pada Staf di Perpustakaan Universitas Sumatera Utara”. Skripsi. Medan: Universitas Sumatera Utara. (http://repository.usu.ac.id/bitstream/123456789/ 14619/1/09E01648.pdf, diakses 4 Januari 2016).

Dinahaji, Haminati Sharikha. 2012. "Pengaruh Pemberian Insentif Terhadap Kinerja Pustakawan di Perpustakaan Daerah Provinsi Jawa Tengah”. (http://download.portalgaruda.org/ article.php?article $=74924 \& v a l=4723$, diakses 1 Juni 2016).

Diniaty, Dewi dan Fairus, Muhamad. 2014. Analisis Faktor-Faktor yang Mempengaruhi Pegawai Perpustakaan UIN Suska Riau. Jurnal Sains, Teknologi dan Industri. Vol.11, No.2, Juni: 297304.

Fauzie, Ahmad. 2009. "Pengaruh Motivasi dan Kompensasi Terhadap Kinerja Pegawai Perpustakaan UIN Syarif Hidayatullah Jakarta”. Tesis. Jakarta: Universitas Indonesia. (http://lib.ui.ac.id/ file?file=digital/123122-T\%2026160-Pengaruh\%20motivasi-HA.pdf, diakses 14 Juni 2016).

Haque, Mahbubul, et al. 2012. Dimensions of Job Satisfaction of Library Professionals: A Qualitative Exploration. International Journal of Business and Social Research (UBSR). Vol.2, No.5, October: 46-62.

Ikonne, Chinyere N. dan Onuoha, Uloma D. 2015. Factor Influencing Job Satisfaction of Librarians in Federal and State University Libraries in Southern Nigeria. OALib. Vol. 2 February. http://dx.doi.org/ 10.4236/oalib.1101337.

Jumarlita, Eka. 2015. "Kepuasan Kerja Staf Perpustakaan: Studi Kasus di Lingkungan Universitas Indonesia”. Skripsi. Jakarta: Universitas Indonesia. (http://lib.ui.ac.id/file?file=pdf/abstrak20160404.pdf, diakses 5 Februari 2016).

Juniantara, I Wayan. 2015. "Pengaruh Motivasi dan Kepuasan Kerja Terhadap Kinerja Karyawan Koperasi di Indonesia”. Tesis. (http://www.pps.unud.ac.id/thesis/pdf_thesis/unud-1227-1924960884tesis.pdf. diakses 23 September 2015).

Kartini, Titin. 2011. "Faktor-Faktor yang Mempengaruhi Kompetensi Profesional Guru di SMK Negeri 1 Losarang Kabupaten Indramayu”. Tesis. Depok: Universitas Indonesia. (http://lib.ui.ac.id/ file?File=digital/20292748-t29824-faktor-faktor.pdf, diakses 18 September 2015).

Kavitha, T. dan Jayarama, S.. 2015. Job Satisfaction of Librarians in Academic Libraries. Library Science, Vol.5, Issue 9, September.: 140-142.

Khoiri, Moh. Mujib. 2013. "Pengaruh Lingkungan Kerja Terhadap Motivasi Kerja Pegawai Perpustakaan di Universitas Negeri Yogyakarta”. Skripsi. Yogyakarta: Universitas Negeri Yogyakarta. (http:// eprints.uny.ac.id/25100/1/Moh\%20Mujib\%20Khoiri.pdf, diakses 2 Maret 2016).

Kinanti, Annisa Queentarina. 2012. "Hubungan Lingkungan Kerja dengan Kepuasan Kerja pada Divisi Sumber Daya Manusia PT Surveyor Indonesia”. Skripsi. Depok: Universitas Indonesia. (http:// lontar.ui.ac.id/file?file=digital/20313763-S-Annisa\%20Queentarina\%20Kinanti.pdf, diakses 20 Januari 2016).

Leysen, Joan M. dan Boydston, Jeanne M. K.. 2009. Job Satisfaction Among Academic Cataloger Librarians. College \& Research Libraries. May: 273-297.

Lim, Sook. 2008. Job Satisfaction of Information Technology Workers in Academic Libraries. Library \& Information Science Research, Vol.30, No.2: 115-121.

Maithili, Visakaruban dan Navaneethakrishnan, Subramanian. 2014. Job Satisfaction of Teacher-Librarians: a Case Study of the Jaffna District, Sri Lanka. Chinese Librarianship: an International Electronic Journal. Vol.38. (www.iclc.us/cliej/cl38MN.pdf, diakses 20 Januari 2016).

Mulyani, Ninuk. 2002. Kompensasi Sebagai Motivator untuk Meningkatkan Kinerja Karyawan. Jurnal manajemen \& kewirausahaan. Vol.4, No.2, September: 108-122.

Murray, Richard A.. 1999. "Job Satisfaction of Professional and Paraprofessional Library Staff at The University of North Carolina at Chapel Hill”. A Master's paper for the M. S. in L. S. degree. February. 56 pages.

Odunlade, R. O.. 2012. Managing Employee Compensation and Benefits for Job Satisfaction in Libraries and Information Centers in Nigeria. Library Philosophy and Practice (e-journal). Paper 714.

Owolabi A.K. dan O, Salaam S. 2010. Job Satisfaction and Organizational Commitment of Academic Librarians in Nigerian Universities. Library Herald. Vol.48, Issue 2:162-170.

Santoso, Hari. 2015. "Peningkatan Kinerja Pustakawan Melalui Perbaikan Lingkungan Kerja (Iklim Organisasi) dan Motivasi Kerja di Perpustakaan Perguruan Tinggi”. (http://library.um.ac.id/images/stories/pustakawan/pdfhasan/peningkatan\%20kinerja\%20pustakawan.pdf, diakses 15 
Maret 2016).

Santoso, Singgih. 2001. Buku Latihan SPSS Statistic Parametrik. Jakarta: PT Elex Media Komputindo. Suharti. 2009. Kepuasan Kerja Pustakawan Universitas Islam Indonesia Yogyakarta. Jurnal Perpustakaan, Vol.2, No.1: 1-13.

Sumbangnisih, Nining dan Nelisa, Malta. 2013. Pengaruh Pemberian Insentif Terhadap Motivasi Kerja Pustakawan di Perpustakaan Universitas Bung Hatta Padang. Jurnal Ilmu Informasi Perpustakaan dan Kearsipan. Vol.2, No.1: 179-185.

Tella, Adeyinka. 2007. Work Motivation, Job Satisfaction, and Organizational Commitment of Library Personnel in Academic and Research Libraries in Oyo State, Nigeria. Library Philosophy and Practice. April: 1-16.

Winarandu, Jeky dan Marlini. 2013. "Faktor-Faktor Penyebab Rendahnya Kinerja Pustakawan di Kantor Perpustakaan, Arsip, dan Dokumentasi (KPAD) Pesisir Selatan”. (http:// download.portalgaruda.org/article.php?article=101352\&val=1516, diakses 20 April 2016). 
